\title{
Model Predicted DMI, Nitrogen (N) Excretion and N Use Efficiency Utilizing Plasma Urea Nitrogen (PUN) Versus Values Estimated in Conjunction with Viable Dry Matter Intake Estimates in Lambs Grazing Pasture
}

\author{
James PS Neel ${ }^{1 *}$, Daniel Moriasi ${ }^{1}$, Michael A Brown ${ }^{1}$ and David P Belesky ${ }^{2}$ \\ ${ }^{1}$ United States Department of Agriculture, Agricultural Research Service, Grazinglands Research Laboratory, El Reno, Oklahoma 73036, USA \\ ${ }^{2}$ West Virginia University, Morgantown 26505-6108 USA
}

*Corresponding author: James PS Neel, USDA-ARS, Grazinglands Research Laboratory, W. Cheyenne St., El Reno, Oklahoma, USA, E-mail: Jim.Neel@ars.usda.gov

Received: 24 Dec, 2018 | Accepted: 18 Feb, 2019 | Published: 22 Feb, 2019

Citation: Neel JPS, Moriasi D, Brown MA, Belesky DP (2019) Model Predicted DMI, Nitrogen (N) Excretion and N Use Efficiency Utilizing Plasma Urea Nitrogen (PUN) Versus Values Estimated in Conjunction with Viable Dry Matter Intake Estimates in Lambs Grazing Pasture. J Anim Sci Res 3(1): doi doi dx.doi.org/10.16966/2576-6457.123

Copyright: (c) 2019 Neel JPS, et al. This is an open-access article distributed under the terms of the Creative Commons Attribution License, which permits unrestricted use, distribution, and reproduction in any medium, provided the original author and source are credited.

\section{Abstract}

A unique Plasma Urea Nitrogen (PUN) model was presented that utilizes animal PUN to predict nitrogen excretion and the efficiency of its utilization in sheep. However, this model has not been evaluated due to limited availability of measured data. Our goal was to evaluate the PUN model's efficacy in a pasture situation using lamb PUN, herbage N, pasture dry matter intake (DMI) estimates, and lamb productivity data from a previous experiment carried out on pasture in the Appalachian mountain region of the eastern USA. Based on the model alone, estimated lamb $\mathrm{N}$ intake and DMI values were calculated utilizing known herbage $\mathrm{N}$ contents and individual lamb PUN values. The model's DMI estimates were much lower $(P<0.01)$ than those utilized in our experiment, and modeled DMI estimates were unrealistic when related to actual animal performance. The model predicted lower $(\mathrm{P}<0.0001)$ intake $\mathrm{N}$ and fecal $\mathrm{N}$, and greater $(\mathrm{P}<0.0001) \mathrm{N}$ use efficiency than that predicted with experimentally utilized $\mathrm{DMI}$ estimates. These results indicate the model needs to be combined with viable DMI estimates to generate realistic outputs, and as we illustrate, viable estimates are easily attainable. We present a method of adjusting the PUN model that would make it a viable tool to help evaluate $\mathrm{N}$ excretion and $\mathrm{N}$ use efficiency within a pastoral system.

Keywords: Pastoral systems; Lamb; Nutritive value; Nitrogen excretion; Nitrogen use efficiency

\section{Introduction}

Global and national security depends on ample food supply to meet domestic and international demand. Food supply is continually being pressured by growth in world population, increasing individual income and uncertainty associated with variable weather and climate. In 2009, the U.N. Food \& Agriculture Organization (FAO) [1] issued a "State of Food \& Agriculture" report, indicating worldwide meat output must double by the year 2050 to meet the increasing desire for meat protein. Consequently, efficient and sustainable livestock production on marginal lands will be an essential part of increased production capacity.

Pasture livestock production systems for small and large ruminants must be resilient when confronted with seasonal and yearly weather variations. These systems must maintain animal and environmental health and integrity, while achieving production goals. The efficient use of system nutrients by plants and grazers is essential to ensure sustainability, environmental health, and reduced production costs. Excess agricultural $\mathrm{N}$ released into the air or entering the water supplies has been stated to be a growing environmental issue [2]. Any excess $\mathrm{N}$ deposited on the ground via urine or feces and not captured within the soil and plant complex, negatively impacts producer income, and increases the potential for $\mathrm{N}$ compounds to enter the atmosphere and water resources [3,4]. In 2001, van Aardenne, et al. [5] indicated that $70 \%$ of $\mathrm{NH}_{3}$ and $30 \%$ of $\mathrm{N}_{2} \mathrm{O}$ released into the environment is livestock related. Since the use of $\mathrm{N}$ fertilizer improves plant and system productivity, an accurate and affordable way to estimate grazer $\mathrm{N}$ use efficiency would be highly beneficial for improving pasture systems.

Increasingly, models are being developed and utilized for predicting farm nutrient flow and use efficiency [6,7]. Although models can be useful tools, it is extremely vital that they are capable of providing realistic information, especially when research conclusions, and management and political decisions are based on their outputs. Nevertheless, assessment of the efficacy of these models is only possible if measured data is available in different regions of the world.

Animal nutrient usage models are primarily developed from confined animal studies where nutrient intake and dry matter intake (DMI), and excretion rates are easily accounted for. In grazing studies 
involving intensively managed pastures, herbage nutrient content is readily estimated, nutritive value is usually high, but estimation of DMI is difficult. The lack of reliable DMI data hinders the model application transition from confined feeding to pasture systems. Kohn et al. [8] used published data from research publications to develop a model that utilizes animal blood urea nitrogen/plasma urea nitrogen (BUN/PUN) to predict nitrogen excretion and the efficiency of $\mathrm{N}$ utilization in sheep. The model was developed by utilizing known animal PUN, intakes and animal production data from intake balance trials. Therefore its applicability in free grazing situations is unknown. Their model is the only one available which utilizes PUN to estimate animal $\mathrm{N}$ usage efficiency and excretion rates in sheep. If applicable for grazing livestock, the Kohn, et al. [8] model would be a valuable tool for systems based grazing research, and indecision making regarding grazing system management.

Based on current literature, this model has not been evaluated with regard to grazing sheep, perhaps due to limited availability of measured data to inform the model. Our goal was to evaluate the PUN model's efficacy in a pasture situation using individual lamb PUN and herbage $\mathrm{N}$ values, experimentally utilized pasture dry matter intake (DMI) estimates, and lamb productivity data from an experiment carried out on pasture in the Appalachian mountain region of the eastern USA.

\section{Materials and Methods}

Kohn, et al. [8] utilized data from 10 publications involving sheep in their model development. They regarded BUN and PUN measurements to be equivalent, "because urea diffuses freely into and out of blood cells". Their model prediction equations were generated utilizing the approach suggested by St-Pierre [9].

Data utilized to evaluate the Kohn, et al. [8] model were collected during the 2003 grazing season and were part of a multiple year study designed to understand management influences on pasture and lamb productivity, and herbage nutritive value [10]. All procedures involving animals during the study were approved by the Appalachian Farming Systems Research Center's Institutional Animal Care and Use Committee. During data collection, wether lambs (2003 grazing season average weight of $32.1 \pm 3.19 \mathrm{~kg}$; mid-winter born Polypay X Suffolk) grazed intensively managed open and silvopasture (either 100\% open pasture system, or a combination of open and silvopasture system). These pastures were located within a small hill-farm in southern West Virginia, USA $\left(37^{\circ} 47^{\prime} \mathrm{N} 81^{\circ} 58^{\prime} \mathrm{W} 860\right.$ m.a.s.l.). Soil at the experimental site was classified as a Dekalb (fine sandy loam, mixed, mesic Typic Hapludult). All pastures were within a $100 \mathrm{~m}$ radius of each other, positioned on a gently rolling ridge-top, and similar in terms of soil classification and slope.

There were 3 grazing system treatments during the grazing season: $100 \%$ open pasture (OP), $67 \%$ OP and $33 \%$ hardwood silvopasture (OS; grazing within wooded area began after grazing of the first 2 OP paddocks in the rotation), and $67 \%$ OP and $33 \%$ hardwood forest pasture delayed (OSD, with grazing within the wooded area beginning after grazing of the 4 OP paddocks in the rotation first), During the experimental period, $\mathrm{N}$ fertilizer was applied to boost herbage production. Nitrogen was applied after completion of the first paddock rotation, generally between mid-and late-May, and to both pasture types at the rate of $33.6 \mathrm{~kg} \mathrm{~N} \mathrm{ha}^{-1}$. A decision to apply $\mathrm{N}$ to all research paddocks was made in an effort to reduce variability related to nutrient availability.

\section{Animal and paddock management}

Four designated "tester" lambs remained on paddocks at all times within their pasture management system treatment. These tester animals were utilized to measure system productivity level, and also for blood draws to evaluate the impact of pasture system on animal plasma urea nitrogen. Additional lambs of similar weight and age were designated for put-and-take stocking to ensure each paddock was grazed for an identical period of time ( 5 days on each paddock during the first spring rotation; 7 days on each paddock henceforth). The number of put-and-take animals varied between paddocks and grazing events since the number needed was based on individual paddock estimated DM availability and current estimated lamb DMIs, prior to each grazing event. For system treatment assignments, lambs were first blocked by weight and needed tester lambs were randomly allotted to replicates beginning with the heaviest lamb. Within replicate, lambs were again blocked by weight and randomly allotted to grazing system treatments. Stocking density was set to remove approximately $60 \%$ of available paddock dry matter (DM) over a specific period of time (initial rotation 5 days; henceforth 7 days) Pasture grazing began on April 21 and ended on September 11, 2003, with the grazing season lasting $143 \mathrm{~d}$. All lambs were provided fresh water and trace mineralized salt at all times, weighed every 28 days, and treated for internal parasites every 21 days with a commercial anthelmintic product.

\section{Measurements}

Experimental spring and summer grazing period designations were defined by measurements being taken either prior to or following summer solstice. Prior to paddock grazing, available herbage DM was estimated utilizing four strategically placed $0.08-\mathrm{m}^{2}$ quadrats per paddock with herbage clipped to a $2.54 \mathrm{~cm}$ residue. Clipped samples were then dried at $60^{\circ} \mathrm{C}$ in a forced-draught oven, and weighed to measure herbage mass. Prior to each grazing event, available herbage DM estimates were used in conjunction with estimated dry matter intakes (DMI) in determining individual paddock stocking rates. The estimated DMIs were calculated based on the most recent average BWs of each paddocks tester animals and put-and-take lambs, the previous 28 day period ADGs of those animals (if necessary) to adjust BWs, and an NRC intake equation (calculations presented below). After paddock DM availability was determined, dried herbage samples were then ground through a 1-mm mesh stainless steel screen in preparation of nutritive value analyses.

Dry matter intake was estimated by: 1) converting individual lamb BW to a cattle equivalent BW (Cattle Equivalent=lamb BW $\times 10$; ([11], see appendix), 2). Utilization of the cattle equivalent weight and the 1996 NRC [12] Beef Cattle DMI equation 7-a: DMI, $\mathrm{kg}=\mathrm{SWB}^{0.75 *}\left(0.1493^{\star} \mathrm{NEm}-0.046^{\star} \mathrm{NEm}^{2}-0.0196\right)$ [with SWB being animal shrunk body weight, and NEm being herbage net energy required for maintenance content] to determine estimated DMI, 3) Cattle equivalent DMI estimates based on the NRC equation were then converted back to a sheep equivalent, on a livestock unit (LU) basis, where a $500 \mathrm{~kg}$ bovine $=1 \mathrm{LU}$ [11]. Sheep DMI=((Cattle DMI/Cattle BW LU) $\times$ Sheep BW LU). As an example, a $318 \mathrm{~kg}$ bovine estimated to consume $7.3 \mathrm{~kg} \mathrm{DM} \mathrm{d}^{-1}(2.3 \% \mathrm{BW})$ of a $1.76 \mathrm{Mcal} \mathrm{kg}^{-1}$ herbage diet by the Beef NRC eq. $7 \mathrm{a}$, would equate to a $32 \mathrm{~kg}$ ovine consuming $0.9 \mathrm{~kg} \mathrm{DM} \mathrm{d}^{-1}(2.8 \% \mathrm{BW})$; Sheep DMI=((7.3 kg DMI/.68 Cattle LU) $\times 0.086$ Sheep LU) $=0.9 \mathrm{~kg}$. During the entire 2003 grazing season, this method of estimating DMI and subsequent determinations of individual paddock stocking rates based on available DM, resulted in a of $93.3 \%$ effectiveness. Changes to calculated paddock stocking rates over the grazing season averaged 0.3 head per paddock per grazing event (data not presented).

Herbage samples were analyzed for concentrations of total nitrogen 
(Carlo-Erba EA 1108 CNS elemental analyzer; Fisons Instruments, Beverly, MA, USA) and acid-detergent fibre (ADF) (Goering and Van Soest, et al. [13]; as modified by Van Soest, et al. [14]). Computations for nutritive value included crude protein (CP) concentration as total $\mathrm{N}$ concentration $\times 6.25$ and metabolizable energy $(\mathrm{ME})$ concentration of herbage as ME ( $\left.\mathrm{MJ} \mathrm{kg}^{-1} \mathrm{DM}\right)=15.3-\left(0.0153 \mathrm{ADFg} \mathrm{kg}{ }^{-1} \mathrm{DM}\right)$ [15]. Net energy for maintenance $(\mathrm{NEm})$ concentrations was calculated from ME estimates [12]

Lamb plasma urea nitrogen (PUN) was determined throughout the grazing season. For PUN measurement, blood samples were taken once per animal during each complete paddock rotation throughout the grazing season. When both the OS and OSD treatments began their first silvopasture paddock allotment for any given rotation, animals for each treatment were placed on their fresh paddocks at approximately 0700 EST (OP and OS; or on OP and OSD paddocks, $10 \mathrm{~d}$ following the OP and OS collection during the first paddock rotation, or $14 \mathrm{~d}$ following the $\mathrm{OP}$ and $\mathrm{OS}$ collection for subsequent paddock rotations). Lambs were allowed to graze for two hours, and then moved to a drylot where they were held without additional feed for 1 hour (while ruminating) prior to blood being drawn at approximately 1000 EST. Individual lamb blood draws were conducted utilizing light green top vacutainers containing Lithium heparin and gel for plasma separation, and via jugular venipuncture. Immediately following the collective blood draw, samples were centrifuged onsite, placed on ice in thermal coolers, and transported for approximately 10 minutes to a local medical laboratory for analysis. For model evaluation, a total of 56 lambs were utilized, which yielded a total of 75 mean individual animal values within both the spring and summer seasons. The allotted amount of grazing time prior to blood collection was determined based on the initial spring introduction of lambs to their fresh paddocks, and the time elapsed when most lambs quit grazing and begin the rumination process.

For the purpose of model evaluation, the following calculations were utilized. For statistical purposes, all calculations were computed on an individual animal basis:

1) Urinary $\mathrm{N}, \mathrm{g} / \mathrm{d}=\mathrm{CR} \times \mathrm{BUN} \times \mathrm{BW}$, where $\mathrm{CR}$ is the $\mathrm{N}$ clearance rate of blood (L of blood cleared/day/kg BW), BUN is blood urea $\mathrm{N}$ $(\mathrm{g} / \mathrm{L})$, and $\mathrm{BW}$ is individual lamb body weight $(\mathrm{kg})$. For our evaluation $\mathrm{CR}=1.2 \mathrm{~L}$ of blood cleared/day/kg BW, this CR value was taken from Table 4, Kohn, et al. [8]; This CR value is suggested by Kohn, et al. [8] to be the maximum CL attainable by sheep and was based on the evaluation of data from nutrient balance trials. For model versus bolstered model comparisons, calculations were done in the same manner.

2) $\mathrm{N}$ Intake $(\mathrm{NI}), \mathrm{g} / \mathrm{d}=\left((\right.$ growth $\left.\mathrm{N}+\mathrm{M}) \times \mathrm{BW}^{0.75}\right) / \mathrm{TD}$, where growth $\mathrm{N}$ is $\mathrm{g}$ of $\mathrm{N}$ retained per $\mathrm{kg} \mathrm{ADG}, \mathrm{M}$ is metabolic $\mathrm{N}$ in $\mathrm{g} / \mathrm{kg} \mathrm{BW} \mathrm{BW}^{0.75}$, and TD is true crude protein digestibility as a \%. For our evaluation $\mathrm{M}=0.02 \mathrm{~g}$ and $\mathrm{TD}=92 \%$, per Table 5 (Kohn, et al. [8]. Growth $\mathrm{N}=29 \mathrm{~g} /$ kg ADG, per Table 6 of Kohn, et al. [8]; For model versus bolstered model comparisons, improved NI estimates were based off equation derived DMI estimates and actual herbage CP content. Growth N was calculated the same in both model runs.

3) Fecal N=NI -UN-growth N; for model versus bolstered model comparisons, UN calculations were the same, while NI calculations differed due to manner of DMI estimation (see number 2 above).

4) $\mathrm{N}$ utilization efficiency, $\%=\left(\right.$ growth $\mathrm{Ng} / \mathrm{NI}$ g) ${ }^{\star} 100$;

5) Kohn, et al. (2005) [8] Estimated DMI, $\mathrm{kg}=\left(\mathrm{NI} \mathrm{gd}^{-1}\right) /($ actual experimental pasture $\mathrm{N} \% / 100) / 1000$
6) Experiment Estimated Lamb $\mathrm{DMI}=((($ Cattle equivalent $\left.\mathrm{SWB}^{0.75 *}\left(0.1493^{\star} \mathrm{NEm}-0.046^{\star} \mathrm{NEm}^{2}-0.0196\right)\right)^{1} /$ Cattle $\left.\mathrm{LU}^{2}\right) \times$ Sheep $\mathrm{LU}^{2}$; with SWB being cattle equivalent shrunk body weight in $\mathrm{kg}$ (eg. 50 $\mathrm{kg}$ ovine $=500 \mathrm{~kg}$ bovine), and NEm being net energy for maintenance content of the pasture in Mcal/ $\mathrm{kg}$, and Cattle LU and Sheep LU being cattle and sheep livestock units for a given equivalent animal weight ${ }^{2}\left({ }^{1}\right.$ Beef NRC [12]; ${ }^{2}$ Minson and Whiteman [11], see appendix). This DMI estimate was utilized during the experiment to determine animal numbers needed per paddock for each grazing event.

\section{Statistical analyses}

For model evaluation, all computations were made on an individual animal basis, with individual animal values within season averaged. Estimate type (EST) comparisons were performed between those generated from the procedure presented by Kohn, et al. [8] utilizing individual animal performance and average weights within season, and those generated from the Kohn model plus experimental DMI estimates and animal data. Data were analyzed using PROC MIXED of SAS (SAS Institute, Cary, NC) as a split, split plot design with the main unit (grazing system, TRT) in a randomized complete block, with SEASON as the first subunit and EST as the secondary subunit. Linear models included the fixed effects of TRT, SEASON, EST and all possible interactions and random effects included REP, REP*TRT, $\mathrm{REP}^{\star} \mathrm{TRT}^{\star}$ SEASON (pooled), and a random residual effect. Grazing system treatment effects and interactions with season and type of estimate were not important since we are only reporting season and estimate type effects. Tests of hypotheses were performed using t tests with $\mathrm{P}<0.05$ considered significant, $\mathrm{P}<0.10$ considered a trend, and $\mathrm{P}<0.15$ considered a weak trend.

\section{Results}

\section{Experimental animal and pasture measurements}

Animal and corresponding herbage nutritive measurements used to evaluate the model are presented as means in table 1 . Lambs were heavier $(\mathrm{P}<.0001)$ in summer than spring. Their ADG was greater $(\mathrm{P}<0.0001)$ in spring than summer. Experimentally utilized lamb DMI estimates (based on the $[11,12]$, and continually monitored paddock $\mathrm{DM}$ removal during each grazing event) was greater $(\mathrm{P}<0.0001)$ in summer than spring. Herbage had a greater $(\mathrm{P}<0.0001) \mathrm{CP}$ in summer compared to spring. Net energy for maintenance (NEm) was greater $(\mathrm{P}<0.0001)$ in summer herbage than spring. Lambs' PUN concentration was greater $(\mathrm{P}<0.0001)$ in summer than spring.

\section{Kohn, et al. [8] estimated $\mathrm{N}$ intake and use efficiencies versus bolstered estimates}

Estimated DMI, intake $\mathrm{N}$, retained $\mathrm{N}$, urinary $\mathrm{N}$, fecal $\mathrm{N}$, and $\mathrm{N}$ use efficiency as influenced by season and estimation method is presented in table 2. There was a season $\mathrm{X}$ estimation method interaction $(\mathrm{P}<0.0001)$ for $\mathrm{DMI}$, intake $\mathrm{N}$, fecal $\mathrm{N}$ and $\mathrm{N}$ use efficiency.

The DMI was greater $(\mathrm{P}<0.0001)$ in summer than spring, and was greater $(\mathrm{P}<0.008)$ for our experimentally utilized estimates than those estimated by the Kohn [8] model alone. The DMI responses estimated by the Kohn model appear to decrease from spring to summer while the experimentally bolstered estimated DMI increased. Intake $\mathrm{N}$ was greater $(\mathrm{P}<0.0001)$ in summer than spring, greater $(\mathrm{P}<0.0001)$ for experimentally bolstered than the Kohn model alone, and appears to increase from spring to summer for experimentally bolstered estimates while only differing slightly (if at all) for Kohn between seasons. As expected, retained and urinary $\mathrm{N}$ did not differ due to use of the same estimation method for both Kohn and those experimentally derived. 
Retained $\mathrm{N}$ decreased $(\mathrm{P}<0.001)$ from spring to summer, while urinary $\mathrm{N}$ increased $(\mathrm{P}<0.0001)$ from spring to summer. Fecal $\mathrm{N}$ was greater $(\mathrm{P}<0.0001)$ for experimentally bolstered values, greater $(\mathrm{P}<0.0001)$ for summer, and appears to increase from spring to summer for experimentally derived while not changing or decreasing across seasons for Kohn. Nitrogen use efficiency was greater $(\mathrm{P}<0.0001)$ for Kohn model alone derived values, decreased $(\mathrm{P}<0.0001)$ from spring to summer, and appears to decrease more for Kohn model derived values versus the experimentally bolstered values.

\section{Discussion}

\section{Animal and pasture measurements}

Lamb weights as presented in table 1 would be considered typical for the spring and summer seasons where lambs are grazing intensively managed pasture in mid-Appalachia, USA. Average daily gains would also be considered reasonable for well managed cool season pasture in West Virginia and they reflect the typical summer slump. It is not unusual for livestock in this area to have low ADG during the summer season, with ADGs dependent on pasture and animal management, environmental conditions, and DMIs.

Experimentally utilized DMI estimates [11,12] for spring and summer were 905 and $1,022 \mathrm{~g} \mathrm{~d}^{-1}$, respectively. The increase in DMI between seasons would be expected since rumen capacity and animal nutritive needs increase as BW increases [16]. If we use these DMIs, the lamb weights from table 1 , and express DMI as a percent of BW, it equates to $3.1 \%$ in spring and $2.9 \%$ in summer. These values are reasonable given the nutritive value of the herbage being grazed [16]. Also, the reduction as a percent of BW going from spring to summer would be expected since, as BW increases DMI as percent of BW would be expected to decrease [16]. We used DMI estimates [11,12] in conjunction with available pasture DM to determine paddock stocking rate prior to each grazing event, with grazing events lasting $5 \mathrm{~d}$ for the first rotation in the spring and $7 \mathrm{~d}$ for the remaining spring and summer rotations. This method of grazing management was extremely effective, requiring few stocking rate adjustments throughout the grazing season, which is indicative of effective DMI estimations. During the experimental period, stocking rates only had to be adjusted $6.7 \%$ of the time (data not shown), and when averaged over the entire grazing season, stocking rates were increased an average of $0.3 \mathrm{hd}$ per paddock.

Herbage CP content was greater $(\mathrm{P}<0.0001)$ in summer than spring. In both cases, $\mathrm{CP}$ is representative of high quality herbage, and the levels would be considered excessive based on animal requirements [16]. Herbage estimated energy content was also greater $(\mathrm{P}<0.0001)$ in summer than spring, although probably not biologically significant for the grazers. Herbage energy content was also indicative of high quality herbage, allowing for relatively high DMIs by the animals grazing it. The high energy content would be expected with intensively managed cool season pastures, where herbage is kept in a vegetative state, and subsequently structural carbohydrate content is minimized. The increase in estimated energy content from spring to summer mirrored the rise in herbage CP content, indicating the rise in energy content was primarily a function of increased herbage CP.As previously stated, during both the spring and summer seasons CP content was in excess of lamb requirements. Once absorbed by the animal from its alimentary tract, amino acids/peptides will be utilized by the grazer for production and maintenance purposes first. Any excess acids/peptides will be utilized as an energy source by the animal, with resultant excess $\mathrm{N}$ either excreted via urine or recycled back to the rumen. Since much herbage CP is highly soluble, and rapidly available in the rumen for microbial degradation (particularly when herbage is in the vegetative state), it is probable that the excess $\mathrm{CP}$ would not be utilizable by the animal as a nutrient source, but rather end up being excreted via urine or feces.

Lamb PUN was lower $(\mathrm{P}<0.0001)$ in spring than summer and is reflective of the lower $\mathrm{CP}$ content of spring herbage. The lamb PUN levels of 0.19 and $0.24 \mathrm{~g} \mathrm{~L}^{-1}$ for spring and summer respectively are within the range of those found in the studies utilized by Kohn, et al. [8] for their model development. Those studies had a range of 0.02 to $0.34 \mathrm{~g} \mathrm{~L}^{-1}$.

\section{Kohn, et al. (2005) [8] Model Evaluation}

Comparisons of $\mathrm{N}$ excretion and $\mathrm{N}$ use efficiency either generated from a model utilizing strictly lamb BUN and performance data [8], or based on the same data plus viable DMI estimates $[11,12]$, are presented in table 2. Retained $\mathrm{N}$ and urinary $\mathrm{N}$ did not differ between estimation methods, as would be expected. This lack of difference between the two is due to retained $\mathrm{N}$ being estimated strictly by multiplying animal ADG by a factor of $29 \mathrm{~g} \mathrm{~kg}^{-1}$ [8]. Experimental ADGs were utilized for $\mathrm{RN}$ estimation in both instances (Kohn [8] versus Beef NRC [12], and Minson and Whiteman [11]). Urinary $\mathrm{N}$ estimates were also generated in a like manner in both cases, where urinary $\mathrm{N}=$ clearance rate $(1.2 \mathrm{~L}$ $\left.\mathrm{kg}^{-1} \mathrm{BW} \mathrm{d}^{-1}\right) \times$ lamb BUN $\left(\mathrm{g} \mathrm{L}^{-1}\right) \times \mathrm{BW}(\mathrm{kg})$, Kohn, et al. [8], thus no difference would be expected.

The DMI differed greatly between estimation methods, with Beef NRC [12], and Minson and Whiteman [11] DMI estimates being 182 and $238 \%$ that of Kohn in spring and summer, respectively. Although the Beef NRC [12] and Minson and Whiteman [11] predicted DMIs and Kohn DMIs are both estimates, our experimental values were effective in managing paddock stocking rates during each grazing event throughout our experiment. Their effectiveness for this purpose clearly demonstrates their more realistic DMI value for the evaluation of nitrogen use efficiency within a pasture situation versus those estimates from the Kohn model. Using the energy content of the herbage, the average weights of the lambs (Table 1) and Kohn derived DMIs, the projected ADG for spring would be $0.0 \mathrm{~g} \mathrm{~d}^{-1}[16]$, and the lambs would be expected to lose weight in summer. Conversely, based on our experimentally utilized Beef NRC [12] and Minson and

Table 1: Experimental lamb average weight (AVE-WT, kg), average daily gain (ADG, g), estimated dry matter intake (DMI, g/d), plasma urea nitrogen (PUN, $\mathrm{g} / \mathrm{l})$, and herbage crude protein (CP, g/kg DM) and net energy maintenance (NEm, Mcal/kg DM) as influenced by spring and summer season.

\begin{tabular}{|c|c|c|c|c|cc|}
\hline Season & $\begin{array}{c}\text { Lamb } \\
\text { AVE-WT } \\
\mathrm{kg}\end{array}$ & $\begin{array}{c}\text { Lamb } \\
\text { ADG } \\
\mathrm{g}\end{array}$ & $\begin{array}{c}\text { Lamb DMI } \\
\mathrm{g} / \mathrm{d}\end{array}$ & $\begin{array}{c}\text { Herbage } \\
\mathrm{CP} \\
\mathrm{g} / \mathrm{kg} \mathrm{DM}\end{array}$ & $\begin{array}{c}\text { Herbage } \\
\text { NEm } \\
\text { Mcal/kg DM }\end{array}$ & $\begin{array}{c}\text { Average } \\
\text { PUN } \\
\mathrm{g} / \mathrm{l}\end{array}$ \\
\hline Spring & 29.5 & 108 & 905 & 141 & 1.53 & 0.19 \\
\hline Summer & 34.7 & 47 & 1,022 & 186 & 1.55 & 0.24 \\
\hline SEM & 0.46 & 4.6 & 11.2 & 4.6 & 0.018 & 0.007 \\
\hline P value & $<0.0001$ & $<0.0001$ & $<0.0001$ & $<0.0001$ & 0.0026 & $<0.0001$ \\
\hline
\end{tabular}


Table 2: Lamb dry matter intake (DMI, g/d), intake nitrogen (IN, g/d), retained nitrogen (RN, g/d), urinary nitrogen (UN, g/d), fecal nitrogen (FN, g/d) and nitrogen use efficiency (NUE, \%), as influenced by estimation method and season.

\begin{tabular}{|c|c|c|c|c|c|c|c|}
\hline Season & Estimation Method & $\begin{array}{l}\text { DMI } \\
\mathrm{g} / \mathrm{d}\end{array}$ & $\begin{array}{l}\text { IN } \\
\mathrm{g} / \mathrm{d}\end{array}$ & $\begin{array}{l}\mathrm{RN} \\
\mathrm{g} / \mathrm{d}\end{array}$ & $\begin{array}{l}\text { UN } \\
\mathrm{g} / \mathrm{d}\end{array}$ & $\begin{array}{l}\mathrm{FN} \\
\mathrm{g} / \mathrm{d}\end{array}$ & $\begin{array}{c}\text { NUE } \\
\%\end{array}$ \\
\hline \multirow{2}{*}{ Spring } & Kohn & 499 & 11.1 & 3.3 & 6.7 & 1.5 & 29.8 \\
\hline & Experimental & 907 & 20.5 & 3.3 & 6.7 & 10.5 & 16.7 \\
\hline \multirow{3}{*}{ Summer } & Kohn & 431 & 12.6 & 1.4 & 10.0 & 1.2 & 10.9 \\
\hline & Experimental & 1,024 & 30.5 & 1.4 & 10.0 & 19.1 & 4.5 \\
\hline & SEM & 11.7 & 0.59 & 0.14 & 0.28 & 0.44 & 0.74 \\
\hline \multirow[t]{2}{*}{$P$ value } & Estimation & 0.008 & $<0.0001$ & 1.0 & 1.0 & $<0.0001$ & $<0.0001$ \\
\hline & Season & $<0.0001$ & $<0.0001$ & $<0.0001$ & $<0.0001$ & $<0.0001$ & $<0.0001$ \\
\hline \multicolumn{2}{|c|}{ Estimation $\times$ Season } & $<0.0001$ & $<0.0001$ & 1.0 & 1.0 & $<0.0001$ & $<0.0001$ \\
\hline
\end{tabular}

Whiteman [11] DMI estimates, the energy content of the herbage, and the average weights of the lambs, spring and summer projected ADGs would be very similar to the reported results (Table 1). This too indicates that our method of estimating lamb DMI is superior to and has greater efficacy than relying on the Kohn model.

Given the results of the two different approaches for estimating $\mathrm{DMI}$, the differences in intake $\mathrm{N}$ are clearer. The intake $\mathrm{N}$ estimates generated from our experimental DMIs and herbage $\mathrm{N}$ content are comparably greater than those generated by the Kohn, et al. [8] model, and are clearly more realistic values. Based on this comparison, the Kohn, et al. [8] model greatly underestimates intake N. The under estimation of intake $\mathrm{N}$ by the Kohn, et al. [8] model leads to under estimations of DMI and fecal N, and the over estimation of $\mathrm{N}$ use efficiency. The model as presented precludes its use for the effective evaluation of $\mathrm{N}$ dispersion and use efficiency within pastoral systems.

If the estimates of retained $\mathrm{N}$ and urinary $\mathrm{N}$ are assumed to be reasonable, which are based on known ADG and BUN data, it appears that the Kohn, et al. [8] model needs to be combined with viable DMI estimates rather than its current method of DMI estimation for it to produce realistic $\mathrm{N}$ use efficiency and balance outputs. However, if utilized with viable DMI intake estimates, the model could be a valuable tool in evaluating $\mathrm{N}$ excretion balance and $\mathrm{N}$ use efficiency within a pastoral system.

\section{Summary}

Since the use of nitrogen fertilizer improves plant and system productivity, an accurate and affordable way to estimate grazer $\mathrm{N}$ excretion and use efficiency would be highly beneficial for improving pasture system provisioning and environmental services. Increasingly, models are being developed and utilized in research, and for prediction of farm nutrient flow and use efficiency. Although models can be very useful tools, it is extremely vital that they are capable of providing accurate information when research conclusions, and management and political decisions are based on their outputs. Availability of valid experimental data, obtained from a study located within a small hillfarm in southern West Virginia, USA, made it possible to evaluate and improve the model developed by Kohn et al. [8] to predict nitrogen excretion and $\mathrm{N}$ utilization efficiency in sheep. Based on their approach of estimating DMI, the Kohn et al. [8] model greatly underestimates intake N. Our evaluation of the Kohn, et al. [8] model shows that it must be combined with viable DMI estimates to generate applicable outputs. Utilization of DMI estimates based on the Beef NRC [12] in conjunction with the animal unit conversion method of Minson and Whiteman [11], provided more realistic and applicable estimates of pastoral $\mathrm{N}$ use efficiency and balance. If applied within these criteria, an improved Kohn, et al. [8] model could be a valuable tool for the estimation and evaluation of $\mathrm{N}$ use efficiency within a pastoral system.

\section{Acknowledgments}

The authors thank biological science technicians Danny Carter and Matt Huffman, Erlend Mathias-agronomist, and Joyce Rucklebiologist, for their many hours of diligent work, and invaluable design discussions and implementations. Trade names are used for convenience of the reader and do not imply endorsement by USDA over comparable products or services. Scientific Article No. 3354 of the West Virginia Agricultural and Forestry Experiment Station, Morgantown. There are no author conflicts of interests.

\section{References}

1. Food and Agriculture Organization of the United Nations (2009) The State of Food and Agriculture-Livestock in the balance. Rome.

2. NRC (2003) Air Emissions from Animal Feeding Operations: Current Knowledge, Future Needs. National Academy Press, Washington, DC.

3. Sharpley A, Meisinger JJ, Breeuwsma A, Sims JT, Daniel TC, et al. (1997) Impacts of animal manure management on ground and surface water quality in Animal. In: Hatfield JL and BA Stewart (eds) Waste Animal Waste Utilization Effective Use of Manure as a Soil Resource. CRC Press, 173-242.

4. Tilman D, Cassman KG, Matson PA, Naylor R, Polasky S (2002) Agricultural sustainability and intensive production practices. Nature 418: 671-677.

5. Van Aardenne JA, Dentener FJ, Olivier JGJ, Klein Goldewijk CGM, Lelieveld J (2001) A $1^{\circ} \times 1^{\circ}$ resolution data set of historical anthropogenic trace gas emissions for the period 1890-1990. Global Biogeochem Cycles 15: 909-928.

6. Hackmann TJ, Spain JN (2010) A mechanistic model for predicting intake of forage diets by ruminants. J Anim Sci 88: 1108-1124.

7. Tedeschi L, Fox D (2014) The utility of applied nutrition models: a brief history and future perspectives.

8. Kohn RA, Dinneen MM, Russek-Cohen E (2005) Using blood urea nitrogen to predict nitrogen excretion and efficiency of nitrogen utilization in cattle, sheep, goats, horses, pigs, and rats. J Anim Sci 83: 879-889.

9. St-Pierre NR (2001) Invited review: Integrating quantitative findings from multiple studies using mixed model methodology. J Dairy Sci 84: 741-755.

10. Neel JPS and DP Belesky (2015) Herbage production, nutritive value and animal productivity within hardwood silvopasture, open and mixed pasture systems in Appalachia, United States. Grass Forage Sci 72: 137-153. 
11. Minson DJ and PC Whiteman (1989) A standard livestock unit (SLU) for defining stocking rate in grazing studies. In: Jarrige R. Proceedings, XVI International Grassland Congress, Nice, France, 1117-1118.

12. NRC (1996) Nutrient requirements of beef cattle. National Academy of Science and National Research Council, $7^{\text {th }}$ edition, Revised, Washington, DC, USA.

13. Goering JK, Van Soest PJ (1970) Forage fiber analyses (apparatus, reagents, procedures and some applications). US. Agricultural Research Service, Washington, DC.
14. Van Soest PJ, Robertson JB, Lewis BA (1991) Methods for dietary fiber, neutral detergent fiber, and nonstarch polysaccharides in relation to animal nutrition. J Dairy Sci 74: 3583-3597.

15. MAFF/ADAS (1987) Energy allowances and feeding systems for ruminants. Reference Book 433. $2^{\text {nd }}$ impression. Her Majesty's Stationery Office, London, England.

16. NRC (1985) Nutrient Requirements of Sheep, $6^{\text {th }}$ edition (revised), National Academy Press, Washington, DC. 


\section{Appendix}

\section{A STANDARD LIVESTOCK UNIT (SLU) FOR DEFINING STOCKING RATE IN GRAZING STUDIES}

D.J. MINSON* and the late P.C. WHITEMAN**

'CSIRO, Division of Tropical Crops and Pastures, Cunningharn Laboratory. St. Lucia, Australia, 4067

Department of Agriculture, University of Queensiand, Australia, 4067

\section{INTRODUCTION}

The weight of arimals and hence their intakes vary between Irazing experiments and at different stages of the same study but the results are often presented as though these differences do not affect graming pressure (Roberts, 1980). Thus we bave hecp tha and cattlefha, with no indication of the effects that differences in intake and hence grazing pressure might have on the pasture/animal interaction. Pastures are utilized by different classes of stock and there is a need to have a common basis for comparing their productivity. These problems would be overcome by the use of a Standard Livestock Unit (SLU). CHOICE OF UNIT

A liveweight of $500 \mathrm{~kg}$ has been used to compare the food requirements of different animal species (Kossila 1984) and measure pasture productivity (Glowatski, 1947). In the United King Kingdom, Pasture productivite recording is based on cattle with a Hveweight of 1 pof Agriculure, Fisheres and Food, 1957 . It appears that a suitable SLU to measure stocking rate in grazing studies would be a non-lactating bovine weighing $500 \mathrm{~kg}$

\section{CONVERSION WITHIN AND BETWEEN SPECIES}

Before the system can be used to convert animal numbers into SLU it is necessary to determine the within animal species and between animal species relationships between forage intake and liveweight.

\section{Within sheep conversion}

Forage intake by sheep increases with body size, but not in direct proportion to body weight. Heavier animals eat less forage per $\mathrm{kg}$ of a. (1960) showed that the ffect of bodyweight could be eliminuted if bodywight is expressed as $\mathrm{kgWW}^{0.75}$, where $\mathrm{W}$ is the weight of the animal. This coefficient has been confirmed in many subsequent studies.

Within cattle conversion

Alder et al. (1960) presented data on the dry matter intake of grazing beef cattle which varied in size from $120 \mathrm{~kg}$ to $570 \mathrm{~kg}$ liveweight. Intake increased with body size but this could be liveweight. Intake increased with body size but this could be made constant if bodyweight was expressed as $\mathrm{kgW}^{0.76}$, which
was not significantly different from the $\mathrm{kgW} \mathrm{w}^{0.35}$ found for shcep.

Between sheep and cattle conversion

When sheep and cattle are fed the same forages it has been shown that the intakes vary between the species as the 0.90

XVT International Grassland Cangress, Nice, France, 1989 power of liveweight (Ternouth et al. 1979). On this basis a $500 \mathrm{~kg}$ steer would eat 7.94 times as much forage as a $50 \mathrm{~kg}$ sheep.

Conversion tuble

Using the 0.75 power of bodyweight for conversion within species, and the 0.90 power between sheep and cattle, the SLU can be derived for animals of different liveweights (Table 1)

The forage intake of goats and sheep are similar when expressed on the basis of the 0.75 power of body weight (Gihad. 1976; Watson and Norton, 1982) so the SLU for pastures graced by goats can be calculated using the conversion factors for sheep (Table 1).

\section{CONCLUSION}

Expressing stocking rates in grazing experiments in the form of SLU would overcome many of the existing problems associated with differences in forage intake within and between razing studies and will enable more valid comparisons to be made. Howcyer it is recognised that intake of animals will be made. Hower it is recognised that intake of a mimals will be altered

Table 1. Factors for converting the number of grazing animals of different species and weight into Standard Livestock Units (500 kg non-lactating bovine).

\begin{tabular}{cccc}
\hline $\begin{array}{c}\text { Liveweight } \\
\text { kg }\end{array}$ & $\begin{array}{c}\text { Sheap } \\
\text { Livestock } \\
\text { units }\end{array}$ & $\begin{array}{c}\text { Liveweight } \\
\text { kg }\end{array}$ & $\begin{array}{c}\text { Cattie } \\
\text { Livestock } \\
\text { units }\end{array}$ \\
\hline 10 & 0.038 & 100 & 0.30 \\
20 & 0.063 & 200 & 0.50 \\
30 & 0.086 & 300 & 0.68 \\
40 & 0.106 & 400 & 0.84 \\
50 & 0.126 & 500 & 1.00 \\
60 & 0.145 & 600 & 1.15 \\
70 & 0.163 & 700 & 1.29 \\
\hline
\end{tabular}

ruminants can eat up to $50 \%$ more pasture than non-lactating animals, while heat stress and disease will depress forage intake (Weston, 1982). In some studies these factors will have to be taken into account but for many purposes no correction will be required when calculating SLU.

\section{REFERENCES}

ALDER, F.E., J.C. TAYLOR, D.T. CHAMBERS, J.A. RICHARDS and J.E. RUDMAN (1960). The herbage of beef cattle. Proc Esghth Internat. Grassi. Congr., 447-450.

CRAMPTON, F.W., DONEFER, E., and LLOYD, L.E. (1960) Nutritive value index for forages. Prac. Eighth intermat. Grassi. Cangr., 462-466.

GIHAD, E.A (1976). Intake, digestibility and nitrogen utilization of trop ical natural grass hay by goats and shoce. J. Anim. SCi. $43: 879-883$. GLOWATSKI, E. (1947). Die Grosswicheinheit. Disch. Land\}, L : 81-82.
KOSSILA, B.L. (1984), Location and potential feed use. In F. SUNDSTL and E. OWFN (eds). Straw and Other Fibrous By-Products as Feed. Elseveir, Amsterdam.

Ministry of Agriculture, Fisheries and Food (1957). The Farm as a Business, p. 44, H.M.S.O., London.

ROBERTS, C.R. (1980). Fffect of stocking rate on tropical pastures. Trop. Grassis $14: 225-231$

TERNOUTH, J.H., POPPI, D.P., and MINSON, D. J. (1979). The voluntary food intake, ruminal retention time and digestibility of two tropical grasses fed to cattle and sheep. Proc. Nutr. Soc.

Aust. $4: 152$.
WATSON, C. and NORTON, L.E. (1982). The utilization of Pangola grass hay by sheep and angora goats. Proc. Awst. Soc, Arim. Prod. 14: $467-470$.

WESTON, R.H. (1982). Animal factors affocting feed intake. In J.B. HACKER (ed.). Nutritional Limits to Pasiture Praduction. Commoowealth Agricultural Bureau, Farnham Royal. 